\title{
Factors that Influencing the Profitability of Saving and Credit Cooperatives: The Case of Boloso Sore District, Wolaita Zone, Southern Region, Ethiopia
}

\author{
Yisehak Ossa Jokka \\ Lecturer, College of Business and Economics, Wolaita Sodo University, Wolaita Sodo, Ethiopia
}

\begin{abstract}
Savings and credit cooperatives are user-owned financial intermediaries. They have many names around the world, including credit unions, SACCOs, etc. Members typically share a common bond based on a geographic area, employer, community, or other affiliation. Members have equal voting rights, regardless of how many shares they own. Savings and credit are their principal services, although many offer money transfers, payment services, and insurance as well. Sometimes savings and credit cooperatives join together to form second -tier associations for the purposes of building capacity, liquidity management, and refinancing. The study was undertaken to identify factors influencing of profitability of saving and credit cooperative in Boloso Sore Woreda Wolaita zone, Southern Ethiopia .The general objective of the study was to identify factors that influencing the profitability of saving and credit cooperatives. A multistage sampling technique was employed to select 305 households from the in order to respond questionnaire. Both quantitative and qualitative data were collected from sampled households. Both descriptive and econometric data analyses techniques were applied. The findings of this study showed that, from the eleven independent variables seven of them significantly affect the profitability of saving and credit cooperative were age, education status, training access, family size, loan repayment, saving habit and service delivery. From this variables training access and service delivery system highly affects the profitability of saving and credit cooperatives. Cooperative development office should train SACCO's members regarding the merit of profitability of saving and credit utilization methods and service delivery showed significant influence on SACCO's member's profitability positively that results increments in profitability. So this requires SACCO's should have to be improved in quality of rendering service relating to service delivery as per established standards on behalf of rules and regulations of SACCO's.
\end{abstract}

Keywords: Saving, credit, cooperatives profitability

DOI: $10.7176 / \mathrm{EJBM} / 11-19-04$

Publication date:July $31^{\text {st }} 2019$

\section{Introduction}

Profit is total earnings for doing business net of operating expenses, depreciation of assets, interest and tax. It also profit as the reward for risk-bearing in undertaking a business activity. The primary objective of any business activity is to maximize shareholders' value through maximizing profit. As defined by in the general sense refers to the ability of a given activity to continue into the future within the likely resources of an organization. In financial terms, sustainability refers to an organization's ability to service all of its expenses through its generated income (GAAP, 2017).

The ultimate goal of saving and credit cooperatives societies are to create savings and mutual assistance among its members by pooling their resources, knowledge and property, to enable them to actively participate in the free market economic system (Proclamation No.147/1998 o Ethiopia). In response to the prevailing supportive government policy and commitment for the development of genuine cooperatives their number and diversity increased rapidly. Nowadays, saving and credit cooperatives in Ethiopia playing multi-functional roles in rural and urban areas (Kifle Tesfamariam, 2015).

Profitability is the most important measure of the success of the business because a business that is not profitable cannot survive (Hofstrand, D, 2009). Profitability can be measured either from accounting perspectives or from economic perspectives. According to accounting perspectives, profit is measured as excess revenue over expenses for a transaction (Stickney, C. P. \& Weil,Edmonds, T. P., McNair, F. M., Millam, E. E. \& Olds, P. R., 2000).

A firm profitability is generally considered as an important precondition for long-term firm survival and success. A firm's performance significantly affects the firm's achievement of other financial goals (Kosmidou et al., 2006). The importance of firm profitability is also manifested in its effect on economic growth, employment, innovation, and technological change. However, due to increasing competition, improved efficiency, and pricing pressure, firms are experiencing greater difficulty attaining the required profit. The question of what factors determine profit should accordingly be one of high priority for both researchers and practitioners, including managers and debt holders. Saving and credit cooperative have poor financial management system and ineffective in their annual profit shareholding. 


\section{Objectives of the Study}

The general objective of the study was to identify factors that influencing the profitability of credit and saving cooperatives in Boloso Sore Woreda.

\subsection{Specific Study Objectives}

The specific objectives of the study were:

1. To identify the factors that affect success of profitability credit and saving cooperatives in the study area.

2. To know the effect of loan repayment on profitability of saving and credit cooperatives in the study area.

3. To investigate the interaction between interest rate on loan and profitability of saving and credit cooperatives in study the area

\section{Methodology}

\subsection{Description of the Study Area}

Boloso Sore Woreda is one of the woredas in the Southern Nations, Nationalities, and Peoples' Region of Ethiopia. Part of the Wolayita Zone, Boloso Sore Woreda on the southwest by Boloso Bombe Woreda, on the east Pulasa woreda, on the northwest by Mirab Badiwacho woreda. Areka is town main its capital town. Boloso Sore Woreda found in wolayta zone which is found at $375 \mathrm{~km}$ south from Addis Ababa, through Hosaina road.It located between 5.72-6.99 ${ }^{0} \mathrm{NN}$ latitude and 27.59-37.86 EE Longitude.

\subsection{Data Sources and Methods Data Collection}

The sources of data were both primary and secondary. In this study, both primary and secondary data were utilized. The primary data were collected from the sample members of saving and credit cooperatives members from sampled kebeles by using a structured questionnaire and interview schedule. Data on all personal, socio-economic, and institutional variables that expected to affect profitability of saving and credit cooperative were collected. Secondary data were gathered from the different records of; woreda Cooperative office, Agricultural and Finance and Economic Development.

\subsection{Sampling Techniques and Sample Size Determination}

Multi stage sampling methods were used in this study and the Boloso Sore Woreda was selected purposively cooperatives. Sample cooperative members were selected via simple random sampling following probability proportional to size (PPS) technique. The number of sample was determined based on (Yamane, 1967) formula to determine the required sample size at $95 \%$ confidence level, and level of precision $=5 \%(0.05)$

Hence, the formula will be as below:

$$
\mathrm{n}=\frac{\mathrm{N}}{1+\mathrm{N}(\mathrm{e})^{2}}
$$

Table 1: Sampled kebeles saving and credit Cooperatives

\begin{tabular}{|l|l|l|l|l|}
\hline $\begin{array}{l}\text { Serial } \\
\text { No }\end{array}$ & \multicolumn{1}{|c|}{ Name of kebele } & $\begin{array}{c}\text { Name of primary } \\
\text { cooperative SACCOs }\end{array}$ & $\begin{array}{c}\text { Total population of } \\
\text { each kebele members }\end{array}$ & Sample size \\
\hline 1 & Adimanicho Arfita & Adimanicho Arfita & 310 & 73 \\
\hline 2 & Bassa Gofara & Bassa Gofara & 423 & 100 \\
\hline 3 & Xiyo Himbecho & Xiyo Himibecho & 242 & 57 \\
\hline 4 & Korke Doge & Korke Doge & 318 & 75 \\
\hline Total & & & $\mathbf{1 , 2 9 3}$ & $\mathbf{3 0 5}$ \\
\hline
\end{tabular}

\subsection{Methods of Data Analysis}

Both descriptive and econometrics methods of data analysis were employed. Descriptive statistics including percentages mean values, frequencies, were used. Econometric analysis was used to measure factors that influencing the profitability of saving and credit cooperatives in consideration of socio-economic, institutional and demographic factors that expected to influence profitability cooperatives.

\subsection{Econometric Analysis}

To identify the factors influencing the profitability of saving and credit cooperatives multiple linear regressions was employed.

\subsubsection{Model Specification}

Multiple linear regression models were used to identify factors influencing profitability of the SACCO's. Linear regression model was employed to account for (predict) the variance in the linear dependent variable based on linear combinations of interval, dichotomous, or dummy independent variables. Multiple regressions can establish that a set of independent variables explains a proportion of the variance in a dependent variable at a significance 
level.

Regression analysis also applied to study how a response variable $\mathrm{Y}$ is dependent on more than one regression variables. For this purpose, a model is adapted to the observations, which explain $\mathrm{Y}$ from all the regression together. The linear regression model for the observations is as follows:

$Y=\beta_{0}+\beta_{1} X_{1}+\beta_{2} X_{2}+\beta_{3} X_{3}+\beta_{4} X_{4}+\beta_{5} X_{5}+\beta_{6} X_{6}+\beta_{7} X_{7}+\beta_{8} X_{8}+\beta_{9} X_{9}+\beta_{10} X_{10}+\beta_{11} X_{11}+U_{i}$ -------------------------------------------------------------------------------------------(1)

In this model $\beta o+\beta 1 \mathrm{X} 1+\beta 2 \mathrm{X} 2+\ldots+\beta 11 \mathrm{X} 11$ are systematic explanatory part of the Model and $\mathrm{E}$ is the random (or unexplained) part of the model. The residual term $\mathrm{E}$ is again assumed to be normally distributed with expectation 0 and variance $0^{2}$. The unknown parameters $\beta o, \beta 1, \beta \mathrm{m}$ are called the regression coefficients. Multiple regression model shares all the assumptions of correlation, linearity of relationships, the same level of relationship throughout the range of the independent variable, interval or near- interval data, absence of outliers, and data whose range is not truncated. In addition, it is important that the model being tested is correctly specified. The exclusion of important causal variables or the inclusion of extraneous variables can change markedly the beta weights and hence the interpretation of the importance of the independent variables (Gujarati, 2004).

Here in this study the dependent variable is profitability of saving and credit cooperative and explanatory variables which affect the dependent variables mentioned and their expected sign is also explained.

$Y=\beta_{0}+\beta_{1} X_{1}+\beta_{2} X_{2}+\beta_{3} X_{3}+\beta_{4} X_{4}+\beta_{5} X_{5}+\beta_{6} X_{6}+\beta_{7} X_{7}+\beta_{8} X_{8}+\beta_{9} X_{9}+\beta_{10} X_{10}+\beta_{11} X_{11}+U_{i}-\cdots \cdot-\cdot$

Where $\mathrm{Y}$ is a function of explanatory variable $\mathrm{X}_{\mathrm{i}}$ and $\mathrm{i}=1 \ldots . .11$ which may be represented below as:-

$\mathrm{X} 1$ is sex of the respondents

$\mathrm{X} 2$ is Educational status cooperative member

$\mathrm{X} 3$ is family size member

$\mathrm{X} 4$ is Age of respondents

$\mathrm{X} 5$ is training access

$\mathrm{X} 6$ is financial management

$\mathrm{X} 7$ is interest rate of SACCOs

$\mathrm{X} 8$ is income of cooperative member

$\mathrm{X} 9$ is service delivery cooperative member

$\mathrm{X} 10$ is saving habit of members

$\mathrm{X} 11$ is saving habit of the cooperative member

Table: 2 Variables Definitions and hypothesized Effect of Explanatory Variables

Own survey result (2019)

\begin{tabular}{|l|l|l|c|}
\hline Dependent variable & Definition and measurement & $\begin{array}{l}\text { Nature } \\
\text { variable }\end{array}$ & $\begin{array}{l}\text { Expected } \\
\text { effect }\end{array}$ \\
\hline Profitability of cooperative & Measured in Ethiopian birr(Y) & Continuous & \\
\hline Independent variables & & & \\
\hline Sex & Sex ( 1 male ,0 female) & Dummy & + \\
\hline Educational status & Educational status (level of education & Categorical & + \\
\hline Family size & Family size of respondents & Continuous & - \\
\hline Age & Age of respondents (in years & Continuous & + \\
\hline Training access & Training access(1 access, other wise 0 & Dummy & + \\
\hline Financial management & Finance mngt(1 has, other wise 0 & Dummy & + \\
\hline Interest rate & Interest rate R in percent & Continuous & + \\
\hline Income & Income in number of birr & Continuous & + \\
\hline Service delivery & Service delivery(1 has, other wise & Dummy & + \\
\hline Saving habit: & Saving habit(1 good other wise 0) & Dummy & + \\
\hline Loan repayment period & Loan repayment period in years & Continuous & + \\
\hline
\end{tabular}

\section{Results and Discussion}

\subsection{Socioeconomic and demographic characteristics of sample households}

As displayed in table 3, the total sample 305 households, male-headed households were about $91 \%$ and remained $9 \%$ were female- headed households, concerned with age status of the respondents about $61 \%$ of the respondents were age between 25 - 35 years old, $29 \%$ of households were $36-50$ years old and the remained $10 \%$ of the respondents were age greater than 51 years. With concerned about educational status of the respondents about $41 \%$ of them were not write and read, about $57 \%$ of respondents achieved primary school, $1.4 \%$ achieved secondary school and $0.6 \%$ achieved Bachelor Degree and above. From the given result we can say that most of them were attained primary school. Regarding about marital status of the respondents, from total sampled households about $270(88 \%)$ were married, about $15(5 \%)$ households were single and $12(4 \%)$ and $8(3 \%)$ of households were 
widowed and divorced respectively (table 3 ).

Table: 3 Socioeconomic and Demographic Characteristics of respondents

\begin{tabular}{|c|c|c|c|c|}
\hline No & Variables & Status of households & Frequency & Percent \\
\hline \multirow[t]{3}{*}{1} & Sex & Male & 278 & 91 \\
\hline & & Female & 27 & 9 \\
\hline & & Total & 305 & 100 \\
\hline \multirow[t]{4}{*}{2} & Age & $25-35$ & 185 & 61 \\
\hline & & $36-50$ & 90 & 29 \\
\hline & & Above 51 & 30 & 10 \\
\hline & & Total & 305 & 100 \\
\hline \multirow[t]{5}{*}{3} & Education & Do not read and write & 125 & 41 \\
\hline & & Primary School & 174 & 57 \\
\hline & & Secondary School & 4 & 1.4 \\
\hline & & Degree and above & 2 & 0.6 \\
\hline & & Total & 305 & 100 \\
\hline \multirow[t]{4}{*}{4} & Marital status & Married & 270 & 88 \\
\hline & & Unmarried & 15 & 5 \\
\hline & & Widowed & 12 & 4 \\
\hline & & Divorced & 8 & 3 \\
\hline Tota & & & 305 & 100 \\
\hline
\end{tabular}

Own survey result (2019)

4.1.1 Factors influences profitability of saving and credit cooperatives

Here, to achieve factors influences profitability of saving and credit cooperatives objective the socioeconomic and institutional variables were included. Based on different literatures multiple linear regression models were employed to identify factors influencing the profitability of saving and credit cooperatives.

In this study the dependent variable was profitability of saving and credit cooperative measured in annual birr the households got from the cooperative and 11(eleven) explanatory variables were used. From these variables, seven variables were significantly affect profitability of saving and credit cooperative, namely age, family size. educational level, training access, income, saving habit and service delivery/facility were found to be significantly influence on the profitability of saving and credit cooperatives( in table 4).

Education (E): It is positive and significantly affecting the profitability of SACCO's. When the educational level of member of improved from primary level to secondary level members of SACCO has good awareness to keep profitability they take from the SACCO's, as result of this the profitability of SACCO's members improved and statically significant at $95 \%$ level of significance. Therefore, it has positive and significant relationship between educational status and profitability. The study result is similar with the previous research done by (Degene debebe, 2016).

Family size (FS): It predicts was found to be significantly and negatively affecting the profitability of saving and credit cooperatives. The family sizes of cooperatives member increased, the annual share of profit of the cooperatives decreased by 0.11 Ethiopian birr. The finding is similar to previous research done by (Danniel Belay, 2006). He said that number of family size negatively affect the profitability saving and credit cooperatives and it was significant at $95 \%$ level of significances.

Age (A): It predicts a positive relationship with profitability, the multiple linear regression models also showed that positive and significant relationship between age of cooperative member and profitability. As age of households becomes elder he /se has good knowledge concerned with saving and financial management skills increased. When age of households increased in one unit the profitability of saving and credit cooperatives increased by 0.12 Ethiopian birr. The finding result is similar with the previous research done by but opposite to previous research done by (Rehman Hafeez, F.M, 2010). It was significant at 95\% level of significances.

Training (T): It was found to be significantly and positively affecting the profitability of saving and credit cooperative in the study area. That means, when the members of SACCO have access to training increased by one unit, level of profitability of SACCO's members is increased by $0.32 \mathrm{ETB}$. This is because of member of saving and credit cooperative betters the knowledge concerning saving and significant at $99 \%$ level of significance it was significant at $95 \%$ level of significances .

Saving habit (SH): Predicts a positive relationship between monthly saving of members of SACCO's members was found to be significantly and positively affecting amount of the profitability of SACCO's members. The profitability of SACCO's members increased 0.11 birr when member saving habit increases by one unit birr. Saving habit of respondent's very important variable and increases the amount profit/dividend for members they take at end of year of auditing and significant at $95 \%$ level of significance. Therefore, we can accept that it has positive and significant relationship between saving habit and profitability. 
Loan repayment (LR): It predicts a positive and significant on the profitability of saving and credit cooperative. When credit delivery and repayment is at better manner to customers, the saving and credit cooperative profit by 0.14 ETB and it was significant at 95\% level of significances.

Services delivery (SD): It was positive and significantly and positively affecting the profitability of saving and credit cooperatives in the area. When the service delivery of SACCOs better and what customers demanded response is responded on time, the cooperative became more profitable. When service delivery improved and added in study area the profitability of saving and credit cooperative increased by 0.142 ETB it was significant at 99\% level of significances.

Table: 4 The Multiple Linear Regression Model Result (Dep. Variable: profitability of saving and credit cooperatives)

\begin{tabular}{|c|c|c|c|c|}
\hline Explanatory Variable & Coefficients & Std. Error & t-value & Sign. \\
\hline (Constant) & 13.056 & 61.45 & 5.11 & 0.34 \\
\hline Sex & 0.234 & 16.142 & 7.456 & .091 \\
\hline Education & .123 & 45.13 & 3.526 & $.015 * *$ \\
\hline Age & .121 & 61.819 & 2.155 & $.022 * *$ \\
\hline Family size & -.113 & 35.13 & 1.43 & $.012 * *$ \\
\hline Training access & .032 & 11.324 & .011 & $.001 * * *$ \\
\hline Income & .120 & 41.536 & 2.011 & .523 \\
\hline Saving habit & .011 & 36.914 & .223 & $.003 * *$ \\
\hline Services delivery & .142 & 53.088 & 2.318 & $.001 * * *$ \\
\hline Loan repayment period & .142 & 53.088 & 2.208 & $.022 * *$ \\
\hline Interest rate & .132 & 43.088 & 2.311 & .322 \\
\hline Financial management system & .132 & 53.088 & 2.308 & .059 \\
\hline R Square Adj & $0.69=69.3 \%$ & & & \\
\hline R Square Adj & $0.63=63.4 \%$ & & & \\
\hline Observations & $\mathrm{n}=305$ & & & \\
\hline
\end{tabular}

Own survey result (2019) significance level *, **, *** 1\%,5\% and $10 \%$ receptively

4.1.2 The effect of loan repayment on profitability of saving and credit cooperatives

In order to attain this objective one way ANOVA was employed to know the interaction between interest rate on loan charged on customers when they take credit and saving services from the saving and credit cooperative.

As depicted in table5 below, the loan repayment SACCO's members in study the areas is significantly associated with the profitability with $1 \%$ level of significance.

This implies that those who pay loan on time can get profit mean profit of 399.62ETB from it and those who did not pay loan on time got the mean profit of 106.26 ETB from the SACCO's members in the study area and standard deviation of 539.96 and 172.42 respectively at $99 \%$ level of significance. The members who pay loan on time got maximum of 3600ETB profit from SACCO's members and minimum of profit 19 ETB from the SACCO's members. Those who did not pay loan on time can get maximum of $840 \mathrm{ETB}$ and minimum of 12ETB profit respectively.

Table: 5 Loan repayments with profitability of saving and credit cooperative

\begin{tabular}{llllllll} 
Loan repayment & $\mathrm{N}$ & Mean & Std.Dev & Min & Max & F-test & Sign \\
No & & & & & & & \\
Yes & 49 & 106.2551 & 172.42 & 12.00 & 840.5 & & .000 \\
Total & 256 & 399.6264 & 539.9 & 19.00 & 3600. & 14.18 & \\
\hline
\end{tabular}

Own survey result (2019) significance level *, **, *** $1 \%, 5 \%$ and $10 \%$ receptively

4.1.3 The interaction between interest rate on profitability of $S A C C O$ 's

In order to attain this objective one way ANOVA was employed to know the interaction between interest rate on loan charged on customers when they take credit and saving services from the saving and credit cooperative.

From the below table 6 shown, the annual profit that the members got from SACCO's positive and significantly affected by interest rate charged on credit. From the total sampled respondents who said interest rate on loan was high got the mean profit of $236.58 \mathrm{ETB}$ and those who responded interest is medium got annual profit 491.42ETB and those who said interest is low were got annual income of 255.65 ETB and the people which said the interest rate of SACCOs is high can expected to get maximum of annual profit of 2600 ETB from SACCOs and minimum of 12ETB. The respondent who said interest rate is medium got the maximum from SACCOs 3600 ETB and minimum of 19 ETB annual profit their annual maximum profit was high than in relation with those who said interest rate of SACCO's is low and high. This is because of those who said high inters rate of SACCOs they cannot borrow more money in it and their annual profit is low in comparison with those who responded interest 
rate of SACCO's was low on credit.

When we compare interest rate charged on loan delivery was significantly affect the annual profit for members at $1 \%$ level of significance with F-test.

Table:6 Interest rate on loan with profitability saving and credit cooperative

\begin{tabular}{lllllll}
\hline Interest rate & Mean & Std. dev & Max & Min & F-test & sign \\
\hline High & 236.58 & 380.45 & 2600 & 12.00 & 9.67 & .000 \\
Medium & 491.42 & 647.28 & 3600 & 19.00 & & \\
Low & 255.65 & 306.69 & 1600 & 17.00 & & \\
\hline Total & 355.93 & 513.12 & 3600 & 12.00 & & \\
\hline
\end{tabular}

Own survey result (2019) significance level $\mathbf{n}=305 *, * *, * * 1 \%, 5 \%$ and $10 \%$ receptively

\section{CONCLUSION AND RECCOMENDATIONS}

5.1 Conclusion

Saving and credit cooperatives help to prevent or overcome poverty, facilitate members' education and they develop a spirit of mutual aid and self-reliance also encourages productivity of its members by providing credit and leads to adopt democratization process at a significant level in SACCO's members. The aims of saving and credit co-operative have always been to mobilize savings from middle and low income groups and supply credit to its members. SACCOs have played a significant role towards achieving the growth and poverty reduction strategy by promoting income generating activities and improving access to near banking services to rural and urban households. The data was collected from 305 SACCO's members and analyzed using descriptive statistics and inferential analysis. Also multiple linear regression models were employed to explain the factors influencing of profitability of saving and credit cooperative (SACCO's) members.

The study was undertaken to identify factors influencing of profitability of saving and credit cooperative in Boloso Sore Woreda Wolaita zone, Southern Ethiopia.

From the eleven independent variables seven of them significantly affect the profitability of saving and credit cooperative were age, education status, training access, family size, loan repayment, saving habit and service delivery. From this variables training access and service delivery system highly affects the profitability of saving and credit cooperatives.

\subsection{Recommendations}

Based on the result of the study, the following recommendations are suggested:

As part of the study, the findings identified major factors influencing the profitability of SACCO's members on Boloso Sore Woreda Wolaita zone, Southern Ethiopia.

Depending on the findings of the study, the following recommendations are given.

$>$ Education status of the households highly in determining members in profitability SACCO's. Therefore, integrating with stakeholders and non- governmental organizations to bring behavioral change for awareness creation on educational status improving saving and credit cooperatives.

$>$ The saving and credit cooperatives shall encourage more savings habit of members to increase profit for SACCO's members.

$>$ The SACCO's should also take into account different internal and external competent regulation and supervision to identify, avoid and resolve many common problems and auditing techniques to improve profitability of SACCO

$>$ Cooperative development office should train SACCO's members regarding the merit of profitability of saving and credit utilization methods

$>$ Service delivery showed significant influence on SACCO's member's profitability positively that results increments in profitability. So this requires SACCO's should have to be improved in quality of rendering service relating to service delivery as per established standards on behalf of rules and regulations of SACCO's

\section{References}

GAAP. (2017). Generally Accepted Accounting Principles.

Kifle Tesfamariam. (2015). Savings and Credit Cooperatives in Ethiopia. Mekell University.

Kosmidou et al. (2006). Euro and profitability of Greek banks. European Research Studies, 3 ( 3-4): 43-56.

Soddo Zuria Woreda agricultural officel. (2012). Rural and Agriculture Department of Soddo Zuria Woreda annual reports, September, 2012. Soddo Zuria Woreda agricultural office.

Statistical office of wolaita zone. (2012). Annual reports of Socio-economic activities. Wolaita zone. 
Stickney, C. P. \& Weil,Edmonds, T. P., McNair, F. M., Millam, E. E. \& Olds, P. R. (2000). Fundamental Financial Accounting Concepts ( $3 r d$ ed). Boston: McGraw-Hill Companies Inc.

Ymmane (1967). Research Methdology. New Age International Limited Publishers. 